\title{
Pengaruh Jenis Mikoriza terhadap Pertumbuhan dan Hasil Beberapa Varietas Cabai Merah (Capsicum annuum L.) pada Tanah Andisol Lembah Seulawah Aceh Besar
}

\author{
Effect of Mycorrhiza Type on Growth and Yields Several Varieties of Red Chili \\ (Capsicum annuum L.) in Andisol Soil Seulawah Valley of Aceh Besar
}

\author{
Muhammad Irfan Kamal ${ }^{1}$, Syamsuddin ${ }^{1}$, Syafruddin $^{1 *}$ \\ *Corresponding author: syafruddin@unsyiah.ac.id
}

\begin{abstract}
Abstrak. Penelitian ini bertujuan untuk mengetahui pengaruh jenis mikoriza terhadap pertumbuhan dan hasil beberapa varietas cabai merah di tanah Andisol. Penelitian ini dilakukan pada bulan Mei hingga Oktober 2019 di Kecamatan Lembah Seulawah, Kabupaten Aceh Besar dan Rumah Kaca Fakultas Pertanian lalu analisis dilakukan di Laboratorium Ilmu dan Teknologi Benih dan Laboratorium Fisiologi Tumbuhan Fakultas Pertanian Universitas Syiah Kuala, Banda Aceh. Analisis data yang digunakan adalah Rancangan Acak Kelompok (RAK) pola faktorial 3 x 3 dengan 3 ulangan sehingga didapat 9 kombinasi perlakuan dengan 3 ulangan mencakup 27 unit percobaan. Faktor yang diteliti yaitu pupuk hayati jenis mikoriza yang terdiri dari 3 taraf (Glomus mosseae, Gigaspora sp. dan campuran antara Glomus mosseae and Gigaspora sp.) dan varietas yang terdiri dari 3 taraf (PM 999 F1, Lado F1, dan Perintis). Hasil penelitian ini adalah perlakuan jenis mikoriza berpengaruh terhadap parameter tinggi tanaman 15, 30 dan 45 HST, diameter batang 30 dan 45 HST, jumlah cabang produktif $60 \mathrm{HST}$, berat basah tanaman, berat kering tanaman, berat basah akar, berat kering akar, berat buah, panjang buah, jumlah buah, dan potensi hasil serta berpengaruh nyata terhadap diameter batang 15 HST dan persentase kolonisasi mikoriza.
\end{abstract}

Kata Kunci: Mikoriza, Cabai merah, Andisol.

\begin{abstract}
This research aims to determine the effect of mycorrhiza type on the growth and yield several varieties of red chili on Andisol soil. This research was conducted from May to October 2019 in Lembah Seulawah District, Aceh Besar District and Greenhouse, and analysis was conducted at the Seed Science and Technology Laboratory and Plant Physiology Laboratory, Faculty of Agriculture, Syiah Kuala University, Banda Aceh. Analysis of the data used in this study was 3 x 3 Factorial Randomized Block Design with 3 replications so that 9 treatment combinations were obtained with 3 replications covering 27 experimental units. Factors studied were mycorrhiza biofertilizers consisting of 3 levels (Glomus mosseae, Gigaspora sp. And a mixture of Glomus mosseae and Gigaspora sp.) and varieties consisting of 3 levels (PM 999 F1, Lado F1, and Perintis). The results of this study are the treatment of mycorrhiza type has a very significant effect on plant height parameters 15,30 and $45 \mathrm{DAP}$, stem diameter 30 and $45 \mathrm{DAP}$, number of productive branches $60 \mathrm{DAP}$, plant wet weight, plant dry weight, root wet weight, root dry weight, fruit weight , fruit length, number of fruits, and yield potential and also have a significant effect on stem diameter 15 DAP and percentage of mycorrhiza colonization.
\end{abstract}

Keywords: Mycorrhiza, Red chili pepper, Andisol.

\section{PENDAHULUAN}

Cabai merupakan tumbuhan yang memiliki perisa pedas diakibatkan senyawa capsaicin. Kebutuhan cabai merah terus bertambah setiap tahunnya seiring dengan bertambahnya jumlah populasi manusia dan perkembangan industri. yang membutuhkan bahan baku cabai sebagai bahan masakan, bahan utama industri seperti saos, bahan tambahan koyo, obat-obatan dan sebagainya. Dengan demikian, stok cabai wajib diperkuatkan melalui peningkatan produktivitas hasil cabai (Herawati, 2014).

Badan Pusat Statistik dan Direktorat Jendral Hortikultura (2019) menyatakan produktivitas cabai di Provinsi Aceh mengalami fluktuatif. Diamati pada hasil cabai daerah 
Provinsi Aceh di 2016 sebanyak 10,367 ton ha ${ }^{-1}$ diikuti di 2017 terjadinya peningkatan hasil sejumlah 11,447 ton ha $^{-1}$, sedangkan pada tahun 2018 hasil cabai turun sejumlah 7,08 \% dari tahun sebelumnya menjadi 10,637 ton ha ${ }^{-1}$. Hasil cabai di Provinsi Aceh masih terbelakang dibandingkan provinsi lain yang ada di Indonesia contohnya pada Provinsi Jawa Barat serta Provinsi Bali. Rendahnya hasil tersebut bisa diakibatkan oleh faktor seperti penggunaan varietas yang tidak sesuai dan unsur hara yang terikat misalnya pada tanah Andisol.

Menurut Nurmasyitah et al. (2013), setiap jenis FMA memiliki keefektifan yang berbeda-beda dalam membantu meningkatkan pertumbuhan dan hasil tanaman. Jenis mikoriza Glomus mosseae memiliki sifat yang lebih aktif tanah dengan dominasi fraksi lempung, kemudian jenis mikoriza Gigaspora sp. memiliki sifat yang lebih aktif di tanah yang berpasir karena pori-pori tanah terbentuk baik sehingga keadaan ini sesuai bagi perkembangan Gigaspora sp. Jenis mikoriza campuran adalah kombinasi dari spora, hifa, vesikel, dan arbuskul dari kelompok endomikoriza (Puspitasari et al., 2012).

Rosliani dan Sumarni (2009) menyatakan inokulasi mikoriza pada pertanian konvensional juga dapat mengurangi aplikasi pupuk NPK sebanyak $25 \%$ dari dosis standar yaitu $100 \mathrm{~kg} \mathrm{ha}^{-1}$ untuk cabai. Zubir et al. (2017) menyatakan pengaplikasian dosis mikoriza $10 \mathrm{~g}$ pada tanah Andisol menunjukan hasil terbaik pada tinggi, diameter batang, kolonisasi akar serta total buah pada cabai. Hal ini diperkuat oleh penelitian Kurniawan et al. (2018), menyatakan diberikannya campuran sebanyak $10 \mathrm{~g}$ dapat menambah penyerapan unsur $\mathrm{P}$ dan tinggi jagung terhadap keadaan cekaman kekeringan.

Penentuan media tanam atau tanah harus diperhatikan dalam peningkatan pertumbuhan dan hasil cabai. Salah satu tanah yang sering digunakan untuk budidaya cabai adalah tanah Andisol. Tanah andisol umumnya dikembangkan untuk tanaman agronomi dan hortikultura. Penyebaran Andisol di Aceh umumnya terdapat di lereng gunung api aktif seperti di Aceh Tengah dan Bener Meriah serta di Kawasan Saree Aceh Besar. Permasalahan utama tanah Andisol saat ini yaitu retensi P yang tinggi (retensi fosfat $>85 \%$ ) oleh karena itu ketersediaan fosfat bagi tanaman cukup rendah. Beberapa penelitian menampakkan bahwa 13\%-15\% dari $\mathrm{P}$ yang diberikan tidak mampu diserap oleh tanaman. Pupuk $\mathrm{P}$ yang sering digunakan para petani saat ini adalah pupuk SP-36 karena mudah didapat dalam jumlah yang relaitf banyak sebagai pemenuh kebutuhan tanaman terhadap unsur hara P. Namun, ketersedian unsur P untuk tanaman belum juga terpenuhi (Mukhlis, 2011).

Tujuan penelitian ini yaitu untuk mengetahui pengaruh pupuk jenis mikoriza terhadap pertumbuhan dan hasil beberapa varietas cabai di tanah andisol lembah seulawah aceh besar.

\title{
METODE PENELITIAN
}

Pelaksanaan penelitian dimulai sejak Mei hingga Oktober 2019 di Kecamatan Lembah Seulawah, Kabupaten Aceh Besar dan Rumah Kaca dan analisis dilaksanakan di Laboratorium Ilmu dan Teknologi Benih dan Laboratorium Fisiologi Tumbuhan Fakultas Pertanian Universitas Syiah Kuala, Banda Aceh.

\section{MATERI DAN METODE}

\begin{abstract}
Alat
Alat yang digunakan adalah cangkul, babybag $(5 \mathrm{~cm} \mathrm{x} 12 \mathrm{~cm})$, kertas label, gunting, sendok, meteran, jangka sorong, gembor, oven, autoklaf, aerator, terpal, ayakan 9 mesh,
\end{abstract}


semprotan air, object glass, cover glass, hot plate, saringan, ajir, plastik tahan panas (isi $5 \mathrm{~kg}$ ), mulsa plastik hitam perak, karet tahan panas, gelas ukur, timbangan analitik, mikroskop lensa 100-400px, kamera dan alat tulis.

\section{Bahan}

Bahan yang digunakan adalah benih Zea mays, benih cabai varietas PM 999 F1, Lado F1, dan Perintis, pupuk hayati mikoriza jenis Glomus mosseae, Gigaspora sp., dan campuran (Glomus mosseae and Gigaspora sp.) dengan dosis masing-masing sebanyak $10 \mathrm{~g}$, pupuk NPK (16-16-16), pupuk kandang, larutan $\mathrm{KOH}$, aquades, larutan Trypan Blue 0,05\% (Quink Parker), insektisida berbahan aktif Imidakloprid dan Triazofos.

\section{Analisis Data}

Rancangan yang digunakan yaitu Rancangan Acak Kelompok (RAK) pola Faktorial $3 \times 3$ dengan 3 ulangan yang terdiri dari dua faktor perlakuan yaitu faktor jenis jenis mikoriza (M) dan varietas cabai (V). Faktor pertama jenis mikoriza (M) terdiri atas 3 taraf, yaitu $\mathrm{M}_{1}$ (Glomus mosseae), $\mathrm{M}_{2}$ (Gigaspora sp.), $\mathrm{M}_{3}$ (Glomus mosseae + Gigaspora sp.). Faktor kedua varietas cabai (V) terdiri atas 3 taraf, yaitu $\mathrm{V}_{1}$ (PM 999 F1), $\mathrm{V}_{2}$ (Lado F1), $\mathrm{V}_{3}$ (Perintis). Penelitian ini terdiri dari 9 kombinasi perlakuan sehingga mencakup 27 unit percobaan, setiap kombinasi perlakuan digunakan 4 sampel cabai sehingga total cabai yang digunakan adalah 108 tanaman percobaan.

\section{Pelaksanaan Penelitian \\ Perbanyakan Mikoriza}

Adapun langkah dalam perbanyakan FMA adalah :

1. Tanah disterilkan menggunakan autoklaf pada suhu $121^{\circ} \mathrm{C}$ selama 30 menit supaya steril dari mikroorganisme yang terdapat di dalamnya.

2. Setelah disterilkan, tanah dimasukkan ke dalam wadah, lubang tanam dibuat dan starter FMA dituang sesuai pemberian $\left(\mathrm{M}_{1}, \mathrm{M}_{2}\right.$, dan $\left.\mathrm{M}_{3}\right)$ dengan takaran $5 \mathrm{~g}$, dimasukkan 2 benih Zea mays per lubangtanam dan ditutup.

3. Pada umur 45 HST, Zea mays akan di stressing dengan memangkas daun dan tidak dilakukan penyiraman selama 30 hari.

4. FMA siap digunakan untuk cabai.

\section{Persiapan Lahan}

Lahan dibersihkan dari gulma, kemudian tanah digali dengan menggunakan cangkul. Kemudian selama 2 minggu dibiarkan, selanjutnya dibuat plot dengan ukuran $18 \mathrm{~m}$ x $1 \mathrm{~m} \mathrm{x}$ $40 \mathrm{~cm}$ dengan antar plot dan drainase yaitu $50 \mathrm{~cm}$.

\section{Persiapan Benih}

Persiapan benih dilakukan dengan memperhatikan kualitas benih cabai yang akan digunakan yaitu memiliki daya berkecambah diatas $90 \%$. Untuk proses perendaman dilakukan menggunakan aerator selama 1 x 24 jam bertujuan untuk meningkatkan daya kecambah benih.

\section{Persiapan Pembibitan}

Masing-masing benih yang digunakan disemai pada tanah Andisol dengan campuran pupuk kandang perbandingan 2:1 yang dimasukkan dalam babybag ukuran $5 \mathrm{~cm} \times 12 \mathrm{~cm}$. Benih ditanam di babybag per satu benih, kemudian mikoriza diberikan sebanyak $1 / 2$ dosis dari $10 \mathrm{~g}$ sesuai dengan pemberian mikoriza. 


\section{Pemberian Pupuk Kandang}

Pupuk kandang sebagai pupuk dasar diaplikasikan sebelum pemasangan mulsa plastik hitam perak sebanyak $18 \mathrm{~kg} \mathrm{plot}^{-1}$ atau setara dengan 10 ton $\mathrm{ha}^{-1}$. Pupuk kandang diberikan dengan cara disebar pada setiap bagian plot atau dicampur rata dengan tanah plot.

\section{Pemberian Mulsa Plastik Hitam Perak}

Pemasangan mulsa dilakukan setelah plot selesai dibuat dan diberi pupuk kandang. Kemudian mulsa dipasang dan dibuat lubang tanam sebanyak dua baris dalam setiap plot dengan jarak tanam $50 \times 60 \mathrm{~cm}$ secara zigzag. Ukuran mulsa yang digunakan adalah $18 \mathrm{~m}$ untuk setiap plot. Karena seluruh plot berjumlah 3, maka total keseluruhan mulsa yang digunakan adalah $54 \mathrm{~m}$.

\section{Pemberian Mikoriza dan Penanaman Bibit}

Pemindahan bibit ke lahan dilakukan diumur 21 hari setelah penyemaian dengan kriteria memiliki 3-5 helai daun. Dibuat lubang tanam dengan kedalaman kurang dari $12 \mathrm{~cm}$. Pemberian $10 \mathrm{~g}$ mikoriza sisa dari pembagian diawal pembibitan dan penanaman bibit sesuai dengan perlakuan.

\section{Pemberian Pupuk NPK}

Pupuk NPK digunakan adalah 50\% dari dosis anjuran $125 \mathrm{~kg} \mathrm{ha}^{-1}$ atau $225 \mathrm{~g} \mathrm{plot}^{-1}$. Pemupukan dilakukan sebanyak 3 kali yaitu setelah pindah tanam, 21 HST dan 42 HST, sehingga setiap pemberian pupuk NPK diberikan sebanyak $75 \mathrm{~g} \mathrm{plot}^{-1}$ dengan melarutkan pupuk NPK dan air sebanyak 15,84 $\mathrm{L}$ plot $^{-1}$ lalu disiramkan sebanyak $220 \mathrm{ml}$ tanaman ${ }^{-1}$ sekitar perakaran.

\section{Pemeliharaan}

Pemeliharaan cabai dilakukan setiap hari sehingga pertumbuhan cabai lebih baik. Pemeliharaan cabai yang dilakukan yaitu penyulaman, penyiraman, penyiangan, pengajiran, pembuangan, pengendalian.

\section{Pemanenan}

Panen dilaksanakan saat berumur 90HST selang 5 hari yaitu buah padat serta warna merah cerah keseluruhan bagiannya mengambil buah dengan tangkai sehingga kesegaran tetap terjaga ketika disimpan.

\section{Parameter Pengamatan}

\section{Tinggi Tanaman (cm)}

Pengamatan tinggi pangkal batang utama hingga titiktumbuh paling tinggi saat berumur 15, 30 dan 45 HST.

\section{Diameter Batang (mm)}

Dilaksanakan di usia 15, 30, dan 45 HST, pangkal batang cabai diukur dengan kaliper.

\section{Jumlah Cabang Produktif (cabang)}

Pengamatan dilakukan dihitung cabang bunga dan buah. Pengamatan dilakukan saat berumur $60 \mathrm{HST}$.

\section{Berat Basah dan Berat Kering Tanaman (g)}

Penimbangan berat segar dilakukan setelah panen ke 7 pada umur 120 HST. Berat kering ditimbang sesudah di oven selama 1 x 48 jam dengan suhu $60^{\circ} \mathrm{C}$. 


\section{Berat Basah dan Kering Akar (g)}

Penimbangan berat segar dilakukan setelah berumur 120 HST. Berat kering akar ditimbang sesudah akar di oven selama 1 x 48 jam dengan suhu $60^{\circ} \mathrm{C}$.

\section{Berat Buah per Tanaman (g)}

Penimbangan buah dilakukan cabai dipanen hingga 7 kali diumur 90 hingga 120 HST. Penimbangan dilakukan menggunakan timbangan analitik kemudian diambil nilai reratanya.

\section{Panjang Buah (cm)}

Pengukuran dilaksanakan setiap pemanenan, yaitu mengambil 5 buah sampel setiap pemberian dan diambil nilai reratanya. Pengukuran dimulai dari pangkal sampai ujung buah dengan menggunakan meteran.

\section{Jumlah Buah per Tanaman (buah)}

Buah yang dihasilkan di hitung pada setiap panen. Perhitungan dilakukan yaitu menjumlahkan seluruh hasil panen pertama sampai panen terakhir.

\section{Persentase Kolonisasi Mikoriza (\%)}

Tanaman dicabut diumur 45 HST untuk diamati persentase akar yang terkolonisasi mikoriza dengan menggunakan mikroskop elektron. Pengamatan dilakukan 9 sample per ulangan dengan menggunakan rumus (Schenck, 1982 dalam Nurhidayati et al., 2010).

$$
\text { Akar terkolonisasi }(\%)=\frac{\text { jumlah akar yang terkolonisasi mikoriza }}{\text { Jumlah akar yang diamati }} \times 100
$$

Lukitanigdyah (2013) mengemukakan bahwa untuk melihat ada tidaknya kolonisasi mikoriza sampel akar dilakukan perwarnaan akar dengan langkah-langkah sebagai berikut :

1. Akar tanaman yang diamati adalah sampel akar tanaman umur 45 HST. Tanaman yang mendapatkan perlakuan dicabut dan diambil akarnya.

2. Akar dicuci dengan air sampai bersih, kemudian direndam dalam larutan $\mathrm{KOH} 10 \%$ selama 24 jam, sampai akar berwarna putih atau kuning bening.

3. Akar dicuci dengan air bersih agar $\mathrm{KOH}-n y a$ hilang dan dipotong-potong dengan ukuran $1-5 \mathrm{~cm}$.

4. Selanjutnya akar diwarnai dengan merendam dalam larutan Trypan Blue 0,05\% selama 24 jam. Setelah itu direndam kembali dalam aquades agar permukaan akar bersih dari pewarnaan biru.

5. Potongan akar dapat diamati dibawah mikroskop dengan pembesaran 100-400 kali.

\section{Potensi Hasil (ton ha ${ }^{-1}$ )}

Potensi hasil dapat dihitung dengan mengkonversikan dari hasil berat buah per tanaman menggunakan rumus berikut :

$$
\text { Hasil }\left(\text { ton } \mathrm{ha}^{-1}\right)=\frac{1 \text { ha- } 15 \%}{\text { Jarak tanam }} \times \text { Berat buah per tanaman }
$$




\section{HASIL DAN PEMBAHASAN}

\section{Pengaruh Mikoriza terhadap Pertumbuhan dan Hasil Cabai}

Berikut adalah rata-rata pengaruh mikoriza terhadap pertumbuhan dan hasil cabai yang dapat dilihat Tabel 1 .

Tabel 1. Rata-rata Pengaruh Jenis Mikoriza terhadap Pertumbuhan dan Hasil Cabai.

\begin{tabular}{|c|c|c|c|c|c|}
\hline & & & enis Mikoriz & & \\
\hline Parameter yang diam & & Glomus & Gigaspora & Camnuran & $\mathrm{BNJ}_{0,05}$ \\
\hline Tinggi Tanaman & $15 \mathrm{HST}$ & $18,25 \mathrm{a}$ & $18,31 \mathrm{a}$ & $21,88 \mathrm{~b}$ & 1,09 \\
\hline & $30 \mathrm{HST}$ & $33,74 \mathrm{a}$ & $36,51 \mathrm{a}$ & $42,36 \mathrm{~b}$ & 2,87 \\
\hline & $45 \mathrm{HST}$ & $61,25 \mathrm{a}$ & $62,26 \mathrm{a}$ & $68,06 \mathrm{~b}$ & 3,75 \\
\hline Diameter Batang (mm) & $15 \mathrm{HST}$ & $2,00 \mathrm{a}$ & $2,08 \mathrm{ab}$ & $2,37 \mathrm{~b}$ & 0,35 \\
\hline & $30 \mathrm{HST}$ & $5,62 \mathrm{a}$ & $5,53 \mathrm{a}$ & $6,41 \mathrm{~b}$ & 0,40 \\
\hline & $45 \mathrm{HST}$ & 7,98 a & 8,16 a & $8,85 \mathrm{~b}$ & 0,45 \\
\hline $\begin{array}{l}\text { Jumlah Cabang Produktif } \\
\text { (cabang) }\end{array}$ & $60 \mathrm{HST}$ & 23,89 a & $23,89 \mathrm{a}$ & $27,93 \mathrm{~b}$ & 2,52 \\
\hline Berat Basah Tanaman (g) & & $178,70 \mathrm{a}$ & $181,94 \mathrm{a}$ & $197,69 \mathrm{~b}$ & 11,89 \\
\hline Berat Kering Tanaman (g) & & $61,06 \mathrm{a}$ & 59,92 a & $68,04 \mathrm{~b}$ & 4,78 \\
\hline Berat Basah Akar (g) & & $9,86 \mathrm{a}$ & $10,19 \mathrm{a}$ & $11,49 \mathrm{~b}$ & 0,61 \\
\hline Berat Kering Akar (g) & & $4,49 \mathrm{~b}$ & $4,00 \mathrm{a}$ & $4,88 \mathrm{c}$ & 0,33 \\
\hline Berat Buah per tanaman $(\mathrm{g})$ & & $161,57 \mathrm{a}$ & $161,29 \mathrm{a}$ & $199,90 \mathrm{~b}$ & 10,28 \\
\hline Panjang Buah (cm) & & $10,64 \mathrm{a}$ & $11,39 \mathrm{~b}$ & $11,92 \mathrm{~b}$ & 0,63 \\
\hline $\begin{array}{l}\text { Jumlah Buah per tanaman } \\
\text { (buah) }\end{array}$ & & $39,00 \mathrm{a}$ & $41,28 \mathrm{a}$ & $51,00 \mathrm{~b}$ & 4,05 \\
\hline $\begin{array}{l}\text { Persentase Kolonisasi } \\
\text { Mikoriza }(\%)\end{array}$ & & $84,44 \mathrm{ab}$ & $82,22 \mathrm{a}$ & $93,33 \mathrm{~b}$ & 10,55 \\
\hline Potensi Hasil (ton $\mathrm{ha}^{-1}$ ) & & $5,39 \mathrm{a}$ & $5,38 \mathrm{a}$ & $6,66 \mathrm{~b}$ & 0,34 \\
\hline
\end{tabular}

Tabel 1 menampakkan bahwa tinggi cabai diumur 15, 30 dan 45 HST tertinggi di jumpai perlakuan jenis mikoriza campuran yaitu 21,88 cm, 42,36 dan 68,06 cm yang berbeda nyata dengan perlakuan jenis mikoriza Gigaspora sp. dan Glomus mosseae. Parameter diameter batang cabai diumur 15 HST terbaik di jumpai perlakuan jenis mikoriza campuran yaitu 2,37 mm yang berbeda nyata dengan perlakuan jenis mikoriza Glomus mosseae namun berbeda tidak nyata dengan perlakuan jenis mikoriza Gigaspora sp. Akan tetapi diumur 30 dan 45 HST diameter batang cabai terbaik di jumpai perlakuan jenis mikoriza campuran yaitu 6,41 $\mathrm{mm}$ dan 8,85 mm yang berbeda nyata dengan perlakuan jenis mikoriza Gigaspora sp. dan Glomus mosseae. Parameter jumlah cabang produktif cabai diumur 60 HST lebih banyak di jumpai perlakuan jenis mikoriza campuran yaitu 27,93 cabang yang berbeda nyata dengan perlakuan jenis mikoriza Gigaspora sp. dan Glomus mosseae. 
Parameter berat buah per tanaman dan jumlah buah cabai terbaik di jumpai perlakuan jenis mikoriza campuran yaitu 199,90 g dan 51 buah yang berbeda nyata dengan perlakuan jenis mikoriza Gigaspora sp. dan Glomus mosseae. Akan tetapi parameter panjang buah cabai terbaik di jumpai perlakuan jenis mikoriza campuran yaitu $11,92 \mathrm{~cm}$ yang berbeda nyata dengan perlakuan jenis mikoriza Glomus mosseae namun berbeda tidak nyata dengan perlakuan jenis mikoriza Gigaspora sp. Parameter bahwa berat basah, berat kering tanaman, berat basah akar dan berat kering akar cabai terbaik di jumpai perlakuan jenis mikoriza campuran yaitu 197,69 g, 68,04 g, 11,49 g dan 4,88 g yang berbeda nyata dengan perlakuan jenis mikoriza Gigaspora sp. dan Glomus mosseae.

Parameter berat buah per tanaman dan jumlah buah cabai terbaik di jumpai perlakuan jenis mikoriza campuran yaitu 199,90 g dan 51,00 buah yang berbeda nyata dengan perlakuan jenis mikoriza Gigaspora sp. dan Glomus mosseae. Akan tetapi parameter panjang buah cabai terpanjang di jumpai perlakuan jenis mikoriza campuran yaitu $11,92 \mathrm{~cm}$ yang berbeda nyata dengan perlakuan jenis mikoriza Glomus mosseae namun berbeda tidak nyata dengan perlakuan jenis mikoriza Gigaspora sp.

Parameter persentase kolonisasi mikoriza akar cabai tertinggi di jumpai perlakuan jenis mikoriza campuran yaitu 93,33\% yang berbeda nyata dengan perlakuan jenis mikoriza Gigaspora sp. namun berbeda tidak nyata dengan perlakuan jenis mikoriza Glomus mosseae. Parameter potensi hasil cabai terbaik di jumpai perlakuan jenis mikoriza campuran yaitu 6,66 ton ha $^{-1}$ yang berbeda nyata dengan perlakuan jenis mikoriza Glomus mosseae dan Gigaspora sp.

Hasil penelitian menampakkan bahwa jenis mikoriza terbaik terhadap pertumbuhan dan hasil cabai di jumpai jenis mikoriza campuran, yang terlihat dari parameter tinggi tanaman 15 , 30 dan 45 HST, diameter batang 15, 30, dan 45 HST, jumlah cabang produktif, berat basah tanaman, berat kering tanaman, berat basah akar dan berat kering akar. Hal ini diduga karena perlakuan jenis mikoriza campuran berasosiasi lebih tinggi dengan akar cabai dibandingkan jenis mikoriza yang lainnya karena jenis mikoriza campuran memaksimalkan kemampuan dua jenis mikoriza untuk kolonisasi terhadap perakaran tanaman sehingga pertumbuhan dan produksi cabai mencapai terbaik. Syafruddin dan Efendi (2012), menjelaskan bahwa mikoriza campuran dan Glomus mosseae biasanya memiliki daya adaptasi dan pertumbuhan yang baik di daerah tercemar dan daerah tropis. Hal ini sejalan dengan pernyataan Azman et al. (2016), mendapatkan bahwa pertumbuhan akar cabai yang diberikan mikoriza Glomus mosseae dan campuran cenderung lebih baik dibandingkan dengan jenis Gigaspora sp. Berdasarkan hasil penelitian Nasution et al. (2018), pertumbuhan dan hasil cabai terbaik di jumpai perlakuan jenis mikoriza campuran berdasarkan parameter tinggi tanaman 30 dan 45 HST, jumlah cabang produktif, berat basah dan kering tanaman, berat basah dan kering akar.

Jenis mikoriza terbaik berdasarkan parameter berat buah per tanaman, panjang buah, jumlah buah per tanaman dan potensi hasil di jumpai jenis mikoriza campuran. Hal ini disebabkan karena jenis mikoriza campuran lebih unggul dalam penyerapan unsur hara $\mathrm{P}$ sehingga dapat meningkatkan hasil cabai. Hal ini sejalan dengan pernyataan Simanungkalit 
(2012), bahwa peran agronomis paling utama dari mikoriza adalah untuk meningkatkan serapan hara $\mathrm{P}$ melalui hifa. Serapan $\mathrm{P}$ oleh hifa sangat dipengaruhi oleh kedekatan hifa permukaan akar dan kualitas hifa. Semakin dekat dengan sumber P, maka serapan P akan semakin tinggi, demikian pula hifa yang cukup berdiumur akan lebih mampu menyerap $\mathrm{P}$ dibandingkan hifa yang belum matang. $\mathrm{P}$ sangat dibutuhkan tanaman pembungaan dan masa pembuahan. Namun potensi hasil cabai dari penelitian ini lebih rendah dibandingkan dengan deskripsi varietas disebabkan oleh jumlah pemanenan yang dilakukan hanya sebanyak 7 kali dibandingkan dengan petani yang melakukan pemanenan 18 hingga 22 kali. Sehingga potensi hasil yang didapatkan lebih rendah dari deskripsi varietas.

Parameter persentase kolonisasi mikoriza di jumpai nilai yang tertinggi perlakuan jenis mikoriza campuran. Hal ini diduga karena perlakuan jenis mikoriza campuran berasosiasi lebih tinggi dengan akar cabai dibandingkan jenis mikoriza yang lainnya karena jenis mikoriza campuran mampu meningkatkan persentase kolonisasi terhadap perakaran tanaman sehingga diharapkan membuat cabai mampu beradaptasi di lingkungan hidupnya. Hal ini disejalan dengan penelitian Syafruddin et al. (2016), menjelaskan bahwa ada beberapa faktor lingkungan yang mempengaruhi perkembangan mikoriza dalam mengkolonisasi akar tanaman antara lain seperti suhu, kadar air tanah, $\mathrm{pH}$, bahan organik tanah, intensitas cahaya, ketersediaan hara, logam berat dan fungisida. Syafruddin et al. (2017), menyatakan bahwa tingkat kolonisasi mikoriza yang tertinggi di dapatkan jenis mikoriza campuran yaitu $90 \%$, hal tersebut terjadi karena hasil biomasa akar dan tajuk tanaman memang lebih banyak didapatkan perlakuan jenis mikoriza campuran dan Glomus mosseae dibandingkan dengan Gigaspora sp. Kondisi lingkungan juga dapat berpengaruh terhadap tingkat daya kolonisasi akar yang sangat tinggi, terutama jenis campuran.

\section{KESIMPULAN DAN SARAN}

Jenis mikoriza berpengaruh terhadap parameter tinggi tanaman 15, 30 dan 45 HST, diameter batang 30 dan 45 HST, jumlah cabang produktif, berat basah tanaman, berat kering tanaman, berat basah akar, berat kering akar, berat buah per tanaman, panjang buah, jumlah buah per tanaman, dan potensi hasil serta berpengaruh nyata diameter batang 15 HST dan persentase kolonisasi mikoriza. Pertumbuhan dan hasil cabai terbaik terdapat perlakuan jenis mikoriza campuran. Saran untuk selanjutnya perlu dilakukan penelitian lebih lanjut mengenai pengaruh jenis mikoriza dan varietas yang berbeda pada tanah Andisol untuk mendapatkan hasil cabai yang optimum.

\section{DAFTAR PUSTAKA}

Azman, S. Syafruddin dan Jumini. 2016. Pengaruh aplikasi mikoriza campuran (Glomus mosseae dan Gigaspora sp.) terhadap pertumbuhan dan hasil beberapa varietas cabai 
(Capsicum annuиm L.) pada tanah entisol. Skripsi. Fakultas Pertanian Universitas Syiah Kuala, Banda Aceh.

Badan Pusat Statistik dan Direktorat Jendral Hortikultura. 2019. Produksi Cabai merah Besar Menurut Provinsi Aceh 2012-2016. http://www.pertanian.go.id [2019].

Herawati. 2014. Budidaya Tanaman Hortikuktura Yang Menguntungkan. Balai Pustaka Press, Jakarta.

Kurniawan, R. A., S. Syafruddin dan Jumini. 2018. Pengaruh jenis mikoriza dan carriernya terhadap pertumbuhan dan hasil jagung manis (Zea mays saccharata Sturt.). Skripsi. Program Studi Agroteknologi Universitas Syiah Kuala, Banda Aceh.

Lukitanigdyah, D. R. 2013. Tingkat persen kolonisasi propagul mikoriza vesikular arbuskula indigenous asal desa Pangpong kec. Labang kab. Bangkalan Madura pada perakaran tanaman padi (Oryza sativa), kedelai (Glycine max), dan tanaman gulma rumput teki (Cyperus rotundus). Paper. Institut Teknologi Sepuluh Nopember Surabaya, Surabaya.

Mukhlis. 2011. Karakteistik kimia tanah andosol pada bebeapa kemiringan lereng di taman hutan raya bukit barisan kabupaten karo. Fakultas Pertanian. Universitas Sumatera Utara, Medan.

Nasution, R. F. Y., S. Syafruddin dan Syamsuddin. 2018. Pengaruh jenis mikoriza terhadap pertumbuhan dan hasil beberapa varietas cabai merah (Capsicum annuum L.) pada tanah inceptisol krueng raya aceh besar. Skripsi. Jurusan Agroteknologi Fakultas Pertanian Universitas Syiah Kuala, Banda Aceh.

Nurmasyitah, S. Syafruddin dan M. Sayuthi. 2013. Pengaruh jenis tanah dan dosis fungi mikoriza arbuskula pada tanaman kedelai terhadap sifat kimia tanah. Jurnal Agrista. 17(3):103-110.

Puspitasari, D., K. I. Purwani dan A. Muhibuddin. 2012. Eksplorasi vesicular arbuscular mycorrhiza (VAM) indigenous pada lahan jagung di desa Torjun, Sampang Madura. Jurnal Sains dan Seni ITS. 1:19-22.

Rosliani, R. dan N. Sumarni. 2009.Pemanfaatan mikoriza dan aplikasi pupuk an organic pada tumpang sari cabai merah dan kubis di dataran tinggi. Jurnal Hort. 19(3):11-12.

Schenck, N. C. 1982. Methods and principles of mycorrhisal research. University of Florida. 22:15-21.

Simanungkalit, R.D.M. 2012. Pengaruh jamur mikoriza vesikuler-arbuskula (MVA), sumber $\mathrm{P}$ dan strerilisasi tanah terhadap pertumbuhan padi gogo di tanah kahat P. Jurnal Biotropic. 16(8):30-38.

Syafruddin, S. and Efendi. 2012. Effect of provisioning bacterial isolates and NP fertilization on total microorganism and degradation level contaminated Inceptisol soil. International Journal Agric. 7:449-456.

Syafruddin, S., S. Syakur and T. Arabia. 2016. Propagation techniques of mycorrhiza biofertiliser with different types of mycorrhiza inoculant and host plant in Entisol Aceh. Internatioanl Journal Agric. 11(2):69-76. 
Syafruddin, S., S. Syakur dan Hasanuddin. 2017. Teknik perbanyakan mikoriza dan adopsi inovasi sebagai biofertiliser dan bioprotektor untuk peningkatan produksi cabai merah pada inceptisol krueng raya aceh besar. Laporan Akhir Penelitian Berbasis Kompetensi. Universitas Syiah Kuala, Banda Aceh.

Zubir, M., S. Syafruddin dan Jumini. 2017. Pengaruh dosis mikoriza campuran (Glomus mosseae dan Gigaspora sp.) terhadap pertumbuhan dan hasil beberapa varietas cabai merah (Capsicum annuum L.) pada tanah andisol burni telong kabupaten bener meriah. Skripsi. Program studi Agroteknologi Universitas Syiah Kuala, Banda Aceh. 